\begin{tabular}{|l|l|l||}
\hline \multicolumn{2}{|c|}{ PublisherInfo } \\
\hline \hline PublisherName & $:$ & BioMed Central \\
\hline \hline PublisherLocation & $:$ & London \\
\hline \hline PublisherImprintName & $:$ & BioMed Central \\
\hline \hline
\end{tabular}

\title{
Switching on genes with GeneSwitch
}

\begin{tabular}{|l|l|l||}
\hline \multicolumn{2}{|c|}{ ArticleInfo } \\
\hline \hline ArticleID & $:$ & 4237 \\
\hline \hline ArticleDOI & $:$ & $10.1186 /$ gb-spotlight-20011029-01 \\
\hline \hline ArticleCitationID & $:$ & spotlight-20011029-01 \\
\hline \hline ArticleSequenceNumber & $:$ & 308 \\
\hline \hline ArticleCategory & $:$ & Research news \\
\hline \hline ArticleFirstPage & $:$ & 1 \\
\hline \hline ArticleLastPage & $:$ & 2 \\
\hline \hline & $:$ & RegistrationDate : 2001-10-29 \\
ArticleHistory & $:$ & OnlineDate $\quad$ 2001-10-29 \\
\hline \hline ArticleCopyright & $:$ & BioMed Central Ltd2001 \\
\hline \hline ArticleGrants & $:$ & \\
\hline \hline ArticleContext & $:$ & 130592211 \\
\hline \hline
\end{tabular}




\section{Jonathan B Weitzman}

Email: jonathanweitzman@hotmail.com

Fruitfly biologists have developed some elaborate genetic tricks to express transgenes in a spatially restricted manner. The bipartite GAL4/UAS system exploits the yeast GAL4 transcriptional activator and the upstream activating sequence (UAS) to which it binds to drive transgene expression. In the October 23 Proceedings of the National Academy of Sciences, Thomas Osterwalder and colleagues at Yale University describe an enhanced conditional, tissue-specific expression system that can take advantage of the range of existing GAL4/UAS fly lines (Proc Natl Acad Sci USA 2001, 98:12596-12601). They created "GeneSwitch", a GAL4-progesterone-receptor fusion protein that can be regulated by the drug RU486. They tested the ability of the GeneSwitch system to drive pre- or postsynaptic expression at Drosophila larval neuromuscular junctions. In an accompanying paper, Gregg Roman and researchers from Baylor College of Medicine report the use of the GeneSwitch system to generate enhancer detector lines with specific expression in the adult head (Proc Natl Acad Sci USA 2001, 98:12602-12607). Now Drosophila researchers have another sophisticated toy to play with, when they wish to regulate transgene expression in time and space.

\section{References}

1. Targeted gene expression as a means of altering cell fates and generating dominant phenotypes.

2. Proceedings of the National Academy of Sciences, [http://www.pnas.org]

3. Yale University, [http://www.yale.edu]

4. Adenovirus-mediated regulable target gene expression in vivo.

5. Baylor College of Medicine, [http://www.bcm.tmc.edu] 